\title{
Information Systems Identification Using TOGAF Framework: A Study Case at PT. X
}

\author{
Muhammad Malik Hakim ${ }^{1}$, Muhammad Imam Ghozali ${ }^{2}$, Wibowo Harry Sugiharto ${ }^{3}$, \\ Ratih Nindyasari ${ }^{4}$, Ahmad Jazuli ${ }^{5}$ \\ \{malik.hakim@umk.ac.id¹,imam.ghozali@umk.ac.id², wibowo.harrys@umk.ac.id ${ }^{3}$ \} \\ Department of Informatics Engineering, Universitas Muria Kudus, Indonesia ${ }^{123}$
}

\begin{abstract}
An Indonesian fast growing IS/IT solution provider is currently aggressively opening branch offices in several major cities. The opening of the branch office then was followed by an increasingly significant number of customers. The quality as well as the intensity of services provided to customers decrease, which then impacts on the decrease in satisfaction level perceived by the existing customers. To address this, research is conducted to identify the necessary information systems using the TOGAF framework. Data collection is done directly through interviews with management, employees, and its corporate customers, and conducts studies on related documents. The results show that the company needs to add features and modules in the form of Online Catalog and Live Chat on some existing applications and build a knowledge management system as a new system.
\end{abstract}

Keywords: strategic planning of information system, TOGAF, ward and peppard, technology architecture, business-IT alignment.

\section{Introduction}

Every company strives to provide the best service to its customers. It is essential because it will impact the loyalty of existing customers and can even be a fascination for new prospects. To deliver the best service to its customers, every company is required to make some improvements both in the external and internal side. Externally, some service improvement is made by providing updated products and services and able to compete in a healthy competition with competitors. Internally, it could be carried out by raising awareness of best service among employees about the importance of providing the best service to customers, improving customer service system in the internal company, and making quality related policy in delivering services to the customer. The best service can be formed in many ways, for example providing accurate and accurate information, processing of administrative affairs and information flow quickly and efficiently, and simplifying technical procedures for customers to self-access the services they need.

PT. X is an Indonesian fast growing national private company that engaged in consulting and providing solutions of IS and IT to its customers currently is striving to adapt and anticipate an ever-increasing number of customers in the past year. The company recognizes the vital role of ICT in providing the best service to its customers. Therefore, the company will perform the planning and identification of the necessary information system in line with the needs of the company to be able to provide the best service to the growing customer.

ICCSET 2018, October 25-26, Kudus, Indonesia

Copyright (C) 2018 EAI

DOI 10.4108/eai.24-10-2018.2280638 
In providing the best service to its customers, the company open branches in several major cities in Indonesia including Jakarta, Bandung, Yogyakarta, Surabaya, Medan, Palembang, Pekanbaru, Balikpapan, Denpasar, and Makassar. The opening of new branch offices in various cities has an impact on the increasing number of customers and the increasing number and scope of services that must be provided to customers as a form of corporate commitment. Significant customer growth makes existing information systems at risk because of limited capacity and capabilities that the system can handle. It makes the company should anticipate by conducting a study to find out the information systems needed that can handle and adapt to the complexity of customers and services that must be delivered to customers. This study aims to conduct studies on information systems/applications that are needed by the company to anticipate future company growth by the business objectives of the company. The identified information system will be determined from the development, whether in the form of modification, addition, and development of features of the existing system, replacement of a system with a new system or do the development of a new system that previously did not exist.

\subsection{Current Research}

Some researchers have researched to develop strategic planning of information systems in a particular agency or industry. Preparation of strategic information system is done using a combination of several methods namely Ward and Peppard, SWOT, and PEST [1]. In another study, a combination of methods was performed by combining Ward and Peppard methods with the Balanced Scorecard Method [2]. Research to develop strategic information system is also done in the education sector especially in higher education. It is done to perform strategic planning of information systems for various purposes, such as about planning for e-learning [3]. Furthermore, other necessities are for future development [4], developmental anticipation [5], and adaptation [6].

In addition to using the Ward and Peppard Method in the above research, strategic information planning can be done using TOGAF Method, where information system planning is one part of it. Researchers who research strategic planning of information systems using TOGAF Method are included in the following research. Strategic planning of information system become part of research to model the enterprise architecture in Health Office Kab. Indragiri Hilir [7]; and in research about college by using a combination of TOGAF and Enterprise Architecture Method [8]. Also, the design of information systems is also a part of making the design of adaptive information technology infrastructure at BATAN (National Atomic Energy Agency) [9]. Furthermore, the TOGAF method can also be used for smaller scales where not all steps in TOGAF should be performed, for example in identifying the needs of e-community applications in Dekranasda Kota Bogor using the TOGAF Method [10]. Some researchers have researched to develop strategic planning of information systems in a particular agency or industry. Preparation of strategic information system is done using a combination of several methods namely Ward and Peppard, SWOT, and PEST [1]. In another study, a combination of methods was performed by combining Ward and Peppard methods with the Balanced Scorecard Method [2].

Research to develop strategic information system is also done in the education sector especially in higher education. It is done to perform strategic planning of information systems for various purposes, such as about planning for e-learning [3]. Furthermore, other necessities are for future development [4], developmental anticipation [5], and adaptation [6]. 
In addition to using the Ward and Peppard Method in the above research, strategic information planning can be done using TOGAF Method, where information system planning is one part of it. Researchers who research strategic planning of information systems using TOGAF Method are included in the following research. Strategic planning of information system become part of research to model the enterprise architecture in Health Office Kab. Indragiri Hilir [7]; and in research about college by using a combination of TOGAF and Enterprise Architecture Method [8]. Also, the design of information systems is also a part of making the design of adaptive information technology infrastructure at BATAN (National Atomic Energy Agency) [9]. Furthermore, the TOGAF method can also be used for smaller scales where not all steps in TOGAF should be performed, for example in identifying the needs of e-community applications in Dekranasda Kota Bogor using the TOGAF Method [10].

\subsection{TOGAF Method}

TOGAF is a method that is used to perform planning infrastructure technology and information systems as a whole. As a holistic development method that includes technology and information systems, TOGAF seeks to harmonize technology architecture with the system well so that IT and enterprise goals are truly aligned and support toward the achievement of the company's overall business objectives.

The steps taken in the TOGAF method are as follows [11]:

1) Phase Preliminary. It is a step intended to know the framework of business architecture within an organization.

2) Phase A: Architecture Vision. This stage is a stage to clearly define the scope, stakeholders, and visions of the existing architecture.

3) Phase B: Business Architecture. At this stage, the business architecture vision is analyzed according to architectural vision, identifying the baseline, targeting, and analyzing the gap between existing business conditions and the desired business conditions in the future

4) Phase C: Information System Architecture. This stage performs an analysis of the architecture of information systems to support the business architecture. Baseline mapping, future SI target fulfillment, and gap analysis will also emerge.

5) Phase D: Technology Architecture. This stage is done to compile information technology architecture that can support information system architecture.

6) Phase E: Opportunities \& Solutions. This stage identifies implementation alternatives, strategies and implementation plans, and identifies the success parameters of the implementation.

7) Phase F: Migration Planning. This stage is done planning the sequence of migration steps from the old architecture to the new architecture with the principle of priority level to adjust to the impact and the benefits it will cause.

8) Phase G: Implementation Governance. At this stage, implementing governance in the implementation of migration projects that include project implementing organizations in system implementation to ensure conformity with the planned architecture.

9) Phase H: Change Management Architecture. At this stage, the establishment of change management architecture to the technology and system has been implemented, monitoring the system operation, and monitoring the changes occurring related to the project implementation to produce the architectural changes as expected. 


\section{Method}

Based on the results of the review of Literature Review, it can be seen that TOGAF method has more comprehensive coverage than Ward and Peppard Method. Ward and Peppard's method is an exclusive method used to perform strategic planning of information system, while TOGAF method is used to perform holistic system and system information technology planning, including strategic planning of information system. This research uses the TOGAF method, to furthermore can be forwarded by the planning of information technology architecture to produce technology architecture and information system which suitable for company business purpose. To undertake the strategic planning of information systems, the phases of TOGAF used include Preliminary Stages, Phase A: Architecture Vision, Stage B: Business Architecture, Phase C: Architecture, and Stage E: Opportunities and Solutions.

In the Preliminary Stage, it will be discussed the problems encountered, identify the target of improvement to the problem, and identification of all possible patterns of solutions. Then, Phase A will contain the identification of the critical processes occurring within the company, and Phase B will identify the business process architecture that occurs in the critical system. Phase $\mathrm{C}$ is then performed by identifying the information system portfolio based on the previous stages of the study. Stage $C$ will proceed with Stage E to perform an analysis gap on existing information systems with the needs of the identified information system. For analysis and identification, data is taken directly to the company conducted through the study documents related companies and conduct interviews to related parties, including corporate management and employees in several divisions as users of the system.

\section{Result and Discussion}

\subsection{Preliminary Stage}

The problems faced by the company are mainly caused by the opening of new branch offices that make the company's customers significantly increased. It causes the needs of customers to the after sales service is increasing, especially for critical products while the limited number of human resources in branch offices and each has different expertise. The impact of it is a waiting period for customers to get after-sales service in case of problems with the product. Also, focusing on the problems faced by customers makes the marketing team less creative in turning problems into opportunities to generate revenue and profits. The identification of the problem is further mapped to obtain improvement objective and possible solution patterns; the problem mapping can be seen in Table 1.

Table 1. The problem to Improvement Target Mapping.

\begin{tabular}{ll}
\hline \multicolumn{1}{c}{ Problem } & \multicolumn{1}{c}{ Improvement Target } \\
\hline $\begin{array}{l}\text { Limitations and differences in technician } \\
\text { expertise. }\end{array}$ & $\begin{array}{l}\text { Increasing the knowledge and expertise of the } \\
\text { technician. }\end{array}$ \\
$\begin{array}{l}\text { Long queue for getting after sales service } \\
\text { The problem cannot be changed into }\end{array}$ & $\begin{array}{l}\text { Increased response to customers } \\
\text { Increasing creativity of sales and marketing team }\end{array}$ \\
\hline
\end{tabular}


Then, by using TOGAF ADM, the company could design the solution pattern based on the identified problem before [12]. possible solution pattern for each improvement objective can be seen in Table 2 .

Table 2. Solution Pattern Identification

\begin{tabular}{ll}
\hline \multicolumn{1}{c}{ Improvement Objective } & \multicolumn{1}{c}{ Solution Pattern } \\
\hline $\begin{array}{l}\text { Increasing the knowledge and } \\
\text { expertise of the technician }\end{array}$ & $\begin{array}{l}\text { Knowledge management feature or applications that allows } \\
\text { sharing of information and cases between technicians }\end{array}$ \\
$\begin{array}{ll}\text { Increased response to customers } \\
\text { Fast communication facilities between customers and } \\
\text { helpdesk } \\
\text { 1. }\end{array}$ & $\begin{array}{l}\text { There is knowledge management on matching between } \\
\text { handling the problem }\end{array}$ \\
$\begin{array}{l}\text { Increasing creativity of sales and } \\
\text { marketing team and to master } \\
\text { product }\end{array}$ & $\begin{array}{l}\text { The existence of complementary or additional product } \\
\text { information to anticipate the occurrence of the problem } \\
\text { The existence of information about product features to } \\
\text { the problems that often occur }\end{array}$ \\
\hline
\end{tabular}

\subsection{Stage A: Vision Architecture}

This stage provides an overview of how the identified solution pattern has a significant role in the company's critical business processes. The identification of critical processes within the company about after-sales services is support services, as well as sales services. These processes are currently managed through a CRM system that records all purchased products and services requested and delivered to customers. While sales service in delivering the best service to the customer, primarily in the process of providing precise information about customer needs by the problem or potential problems that would occur after product have been delivered. The Architecture vision has to be inline with the company's vision in achieving its goals [12].

\subsection{Stage B: Business Process}

The critical business process associated with the after-sales service begins with problem information from customers to the helpdesk division, then the helpdesk division will inform the technical division of the problem faced by the customer in detail. Furthermore, the technical division will allocate the available technician personnel to immediately make contact to the customer in response, to determine the service to be provided to the customer, whether guiding via telephone or onsite services by the level of problems encountered. If the service has been carried out, the customer and the technician will report whether the problem is resolvable or not, or require additional parts. While the critical business processes associated with the sales team about the problems faced by the customer is when the customer needs additional spare parts and other products to solve the problems encountered. Based on the information from the technician, the sales team can order the required product through the sales admin system which will be processed and delivered to the customer according to the availability of the needed product or spare parts. This business process understanding is very important to indentify the application needs that would be committed in the next step [13]. 


\subsection{Stage C: Identification of Application Needs / Information Systems}

Critical business processes are later analyzed and mapped according to the identified solution pattern. This is conducted to find out the appropriate solution package for each solution pattern. These solution pattern modelling is conducted using business capability map [14]. The solution package identified according to the solution pattern mapping can be seen in Table 3 .

Table 3. Solution Packet Mapping.

\begin{tabular}{ll}
\hline \multicolumn{1}{c}{ Solution Pattern } & \multicolumn{1}{c}{ Solution Packet } \\
\hline $\begin{array}{l}\text { Knowledge management feature or applications that allows sharing of } \\
\text { information and cases between technicians }\end{array}$ & $\begin{array}{l}\text { Knowledge } \\
\text { Management }\end{array}$ \\
$\begin{array}{l}\text { Fast communication facilities between customers and helpdesk } \\
\begin{array}{l}\text { 1.There is knowledge management on matching between handling the } \\
\text { problem. }\end{array}\end{array}$ & $\begin{array}{l}\text { Live Chat } \\
\text { a. Knowledge } \\
\text { 2.The existence of complementary or additional product information to } \\
\text { anticipate the occurrence of the problem. }\end{array}$ \\
$\begin{array}{l}\text { 3.The existence of information about product features to the problems } \\
\text { that often occur }\end{array}$ & b. Online Catalog \\
\hline
\end{tabular}

The solution package that has been mapped by Table 3 should have functionality that supports the company to provide the best service to the customer. The solution package functionality can be seen in Table 4 .

Table 4. Solution Packet Functionality.

\begin{tabular}{ll}
\hline \multicolumn{1}{c}{ Solution Packet } & \multicolumn{1}{c}{ Functionality / Feature } \\
\hline & - Share knowledge between technicians and sales teams. \\
& - Have information about the case on the problem that occurred \\
& - Could record problem identification \\
& - Have a note about the step of problem handling \\
Knowledge & - Have a feature that can search for problems that ever \\
Management & happened \\
& - Have a feature that can compare the same problems with \\
& different solutions \\
& - Have information that can match the problem with the \\
& necessary alternative spare parts \\
& - Have a feature chat via text, sound, and image/video \\
& - Have an information status (online/offline) \\
Live Chat & - Can perform a record of the chat done
\end{tabular}


- Accessible to customers, sales teams, and HR Technicians

- Have a solution in matching problems that occur with alternative products and spare parts that may be needed

Online Catalog

- Have information with the stock availability of product and spare parts

- Have information on current prices.

- Have an online order feature and order processing online

\subsection{Gap Analysis}

Gap analysis is done to analyze the existing application/information system with the application required by the company. Applications that currently exist within the company are analyzed in detail about the functionality and the features present in it when compared with the application/information system needed. Based on these comparisons a recommendation is made of adding or reducing features or modules in existing applications, developing new systems that did not exist previously, or integrating existing systems where possible. The gap can be seen in Table 5 .

Table 5. Gap Analysis.

\begin{tabular}{lll}
\hline Existing Application & \multicolumn{1}{c}{ Needed Application } & Recommendation \\
\hline & Company Portal & \\
Company Portal & - Online Catalog & - Update Feature \\
& - Product Information & - Add Modul \\
& - E-commerce & \\
& - Live Chat & \\
CRM & CRM (Customer Service & - Add Modul \\
- & Log Report) & - Develop new System Information \\
\hline
\end{tabular}

Based on the gap analysis, it can be seen the company need the new and updated application/information system to provide services to customers. It can be fulfilled in several ways, such as the addition of new features and a new module on the corporate portal, the addition of modules on CRM applications, and development of Knowledge Management (KM) system as a new information system needed.

\section{Conclusion}

This research conclude that in order to give the best service to the customers, the company has to add features and modules to some existing system, and to develop new system that enable the employees to committed business process online easily and quickly so that the service to the customer can be done more responsively, adaptively, faster, more effectively, and efficiently. 


\section{References}

[1] M. and J. Antoni, D., Akbar, "Portfolio Aplikasi untuk Industri Kelapa Sawit di Kabupaten Musi Banyuasin," J. SIMETRIS, vol. 8, pp. 693-700, 2017.

[2] R. Hannesto, "Perencanaan Strategis Sistem Informasi pada PT. Indah Kiat Pulp \& Paper, Tbk," ComTech, vol. 5, pp. 905-916, 2014.

[3] I. P. M. Dewi, K. C. and Astawa, "Perencanaan Strategis E-Learning Politeknik Negeri Bali Menggunakan Ward and Peppard Framework," J. Matrix, vol. 6, pp. 74-79, 2016.

[4] W. P. Putra, "Perancangan Strategi IT Politeknik Negeri Indramayu Menggunakan Pendekatan Ward and Peppard," J. Inform., vol. 9, pp. 1106-1114, 2015.

[5] W. Syafitri, "Perencanaan Strategi Sistem Informasi /Teknologi Informasi Universitas Lancang Kuning Menggunakan Metode Ward and Peppard," Digit. Zo. J. Teknol. Inf. Komun., vol. 7, pp. 3143, 2016.

[6] D. Sabtu, J., Sussolaikah, K., and Karim, "Perancangan Strategi Sistem Informasi Akademi Ilmu Komputer (AIKOM) Ternate," J. Ilm. Multitek Indones., vol. 11, pp. 59-68, 2017.

[7] G. W. Rianto, B., Lidya, L., and Nurcahyo, "Pemodelan Arsitektur Enterprise Menggunakan TOGAF ADM Studi Kasus Dinas Kesehatan Kabupaten Indragiri Hilir,” J. Komput. Terap., vol. 2, pp. 55-68, 2016.

[8] H. Kusbandono, "Pemodelan Arsitektur Enterprise Menggunakan TOGAF ADM untuk Mendukung Sistem Informasi Proses Akademik pada Universitas Muhammadiyah Ponorogo," J. Ilm. Multitek Indones., vol. 8, pp. 16-35, 2014.

[9] D. et. al Hernikawati, "Perancangan Infrastruktur Teknologi Informasi Adaptif pada Badan Tenaga Nuklir Nasional.," J. Penelit. Komun., vol. 19, pp. 179-192, 2016.

[10] Y. Andriariza, "Identifikasi Aplikasi E-Komunitas Industri Kreatif Sektor Kerajinan Dekranasda Kota Bogor," J. Penelit. Pos dan Inform., vol. 6, pp. 93-108, 2016.

[11] T. O. G. A. Forum, “TOGAF® Version 9.1, Enterprise Edition. The open Group, US,” 2011. .

[12] J. Bondar, S., Hsu, J. C., Pfouga, A, and Stjepandic, "Agile Digital Transformation of System-ofSystems Architecture Models Using Zachman Framework," Jounal Ind. Inf. Integr., vol. 7, pp. 33-43, 2017.

[13] A. et. al. Haghighathoseini, "Hospital Enterprise Architecture Framework (Study of Iranian University Hospital Organization)," Int. J. Med. Inform., vol. 114, pp. 88-100, 2018.

[14] et al. Brefort, D., "An Architectural Framework for Distributed Naval Ship Systems," Ocean Eng., vol. 147, pp. 375-385, 2018. 